\title{
Blogs as a Tool for the Development of Self-Regulated Learning Skills: A Project
}

\author{
Consuelo Martínez Priego ${ }^{1}$, Guiomar Nocito Muñoz ${ }^{1}$, Monika Ciesielkiewicz, ${ }^{2, *}$ \\ ${ }^{1}$ Department of Phychopedagogy, C.U. Villanueva, Complutense University of Madrid, Madrid, Spain \\ ${ }^{2}$ Department of Applied Didactics, C.U. Villanueva, Complutense University of Madrid, Madrid, Spain \\ *Corresponding author: mciesielkiewicz@villanueva.edu
}

Received December 16, 2014; Revised, December 30, 2014; Accepted January 08, 2015

\begin{abstract}
In the last decade projects have been emerging aimed at promoting the competency of self-regulation through didactic resources included in college curriculum. The use of strategies for self-reflection and selfevaluation while the course material is being taught favors self-regulation of students and increases their level of self-efficacy regarding the content of the course. The goal of this didactic experience is to develop self-regulation learning skills through a systematic use of ICT's, in particular, a blog as a teaching and learning tool. It was implemented as a part of Sociology of Education course whose content is mostly theoretical and requires an advanced level of reflection and internalization of concepts that were completely unfamiliar to the students. The experiment is designed to: [a] encourage well-organized and consistent work habits, by establishing sufficient periods of time for students that would give them enough autonomy to make decisions; [b] to promote reflection on topics covered in class; [c] to facilitate a dialogue among students that promotes reflection aimed at forming a learning community. Said project demonstrates that further research, both qualitative and quantitative in nature, on the impact of the use of blogs for the development of the competencies identified above, is not only possible but would likely provide very useful data.
\end{abstract}

Keywords: self-regulated learning skills, self-regulation, autonomy, reflection, blog, ICT, project, education

Cite This Article: Consuelo Martínez Priego, Guiomar Nocito Muñoz, and Monika Ciesielkiewicz, "Blogs as a Tool for the Development of Self-Regulated Learning Skills: A Project.” American Journal of Educational Research, vol. 3, no. 1 (2015): 38-42. doi: 10.12691/education-3-1-8.

\section{Introduction}

The management of learning can now be considered as one of the fundamental pillars of pedagogy, and one whose importance has increasingly been appreciated during the current century. The Commission of European Communities (2000) in the Memorandum of Lifelong Learning stated that self-regulated learning is considered a necessary prerequisite for continuous lifelong learning.

At the same time the European Report on the Quality of School Education (European Commission, 2000), which expresses the final conclusions of a workgroup formed by experts from the Departments of Education of 27 countries established 16 indicators that constitute the basis of a quality educational system. One of them is the ability to "learn how to learn" which is considered the key indicator of success in the workplace and in society in general. This has been identified as a high priority in European educational policy. "The challenge consists in guaranteeing that the skills related to learning how to learn become our political priorities with a view to adapt them to school programs (...)” (p. 24).

In the same vein, the Commission of the European Communities (2006) sets forth that the ability of learning how to learn as one of the key skills for lifelong learning.
It also asserts that self-regulation of learning becomes a necessary skill for university students in European System of Education (Wirth and Leutner, 2008).

Gargallo and Ferras (2000) affirm that a vast amount of information and content in today's world makes the knowledge of strategies to handle that information crucial in order to continue learning throughout one's life.

Learning strategies in a context of self-regulated learning from an Anglo-Saxon perspective entails the integration of various dimensions such as cognitive, metacognitive, motivational, and environmental, all of them necessary for the completion of academic assignments. Therefore, self-regulation of learning has become a fundamental requirement in the society of information and communication.

Pozo and Monereo (2000) argue that this requirement has generated a new culture of learning that puts great emphasis on acquisition of strategies, both in basic general education as well as in college or university, which focuses on the mechanisms that help students to manage their own learning.

Despite the fact that self-regulation of learning is a quite complex construct, according to Boekaerts, Maes and Karoly (2005), the majority of researchers agree that self-regulation involves multiple competencies, as well as an iterative and self-directed process applied to one's skills, emotions, actions and environment that should be 
tailored to serve one's own objectives (p. 150). It can be claimed that self-regulation of learning is probably the quintessential skill of the active core of all abilities which allows one to control a wide range of behaviors in diverse areas, situations and contexts (Sitzmann and Ely, 2011).

It is known that students who apply self-regulation strategies are active participants in their learning process. They establish clear goals, select and apply effective strategies, as well as are able to control their own emotions. (Zimmerman, 2008).

García (2012) gathered the contributions of various relevant studies on the characteristics of students who regulate their learning, conducted in recent years (Gargallo and Ferreas, 2000; A. González, 2001; Monereo, 2001; Núñez, González-Pienda and Rosario, 2006; Torrano and González, 2004; Torre, 2007). He specified the following attributes (p. 211):

- They are aware of the correlation between selfregulation processes and academic success. Therefore, whenever they face a new learning task, they consider it important, engage personally and feel capable to carry it out, as well as use appropriate resources in order to succeed in it. They are fully aware of the fact they are active agents in their learning, as well as responsible of the final product.

- They are aware of their skills and knowledge, as well as what they should do to learn successfully. They know strategies that work for them. They are also able to adjust and reorganize their strategies and behavior to new learning goals, activities and tasks that they set for themselves, monitoring their behavior through continuous, both mental and oral, feedback.

- They are aware of their emotions and capable of controlling their negative emotions, so that they do not affect their achievement. This way, they are also able to motivate themselves, work hard and feel competent.

- They apply different types of strategies such as cognitive, metacognitive, motivational and support strategies and consider them important. Apart from that, they are fully aware of the direct relation between selfregulation strategies and their learning objectives.

- They supervise the efficacy of their habits and learning strategies changing one strategy for another one which they find more useful and efficient, or making necessary adjustments in their physical and social environment taking personal initiative and being perseverant in order to achieve their goals.

- They know how to create favorable study environment choosing the right place to study, avoiding external and internal distractions and asking for help both their professors, as well as classmates whenever they face difficulties.

- They are able to transfer their self-regulation strategies into other very diverse situations and contexts, both academic as well as in their daily life.

Not all students who start college have these characteristics. Hofer, $\mathrm{Yu}$ and Pintrich (1998) state that indeed "a lot of adult learners and students do not selfregulate their learning until they learn about the nature of the development of self-regulated learning through formal interventions which help them to improve their own selfregulation” (p. 57).
It is evident that the number of students who attend university with insufficient preparation and shortfall of learning strategies and resources has been growing in recent years. (Hernández, Rosario and Cuesta, 2010).

Randi and Corno (2000) point out that the majority of education environments offer very few opportunities for self-regulation to students. Therefore, it is not surprising that they are unable to use them and that they are having a hard time managing some activities that they are asked to do, especially those that require a higher degree of selfcontrol and better knowledge of complex strategies. In addition, many students are not very well prepared and are not flexible or able to adapt enough to identify the opportunities to self-regulate their learning or to apply previously learned strategies in new situations. However, teaching self-regulation strategies and practicing them in class can create opportunities that help students manage and monitor their learning. Teachers can deliberately create assignments that promote development of selfregulating skills in class based on general curriculum that teaches different ways of knowledge acquisition. Román (2004) affirms that teaching how to learn through a curriculum as a central driver is possible at the university level. It can be done through optimizing and activating cognitive processes and procedures. Saínz, Montero, Bol and Carbornero (2012) also add that professors need to analyze and explain metacognitive strategies in class and assist students in acquiring and applying them. As a result, it would help students to better learn course material and promote self-regulated learning. According Kramarski and Michalsky (2009) self-regulated learning is not acquired spontaneously, and these strategies can be developed through participation in experiences and environments that provide the opportunity for students to regulate their own learning.

Lloret and Mir (2007) point out that the methodological renewal that Bolonia Plan increases demands for students and professors since active learning requires more student's dedication and engagement. As for professors, this new methodological approach demands more preparation of classes, materials and activities, more attention, tracking of students learning and new technical and didactic knowledge.

On the other hand, research on self-regulated learning from the last decade has taken into account new technologies in higher education (Andrade and Bunker, 2009; Azevedo, 2005; Acevedo, 2010; Azevedo and Cromley, 2004; Ciesielkiewicz, 2012; Geddes, 2009; Grahame and Ardenson, 2003, Lee, Lin and Grabowski, 2010; Leutner, Leopold and Elzen-Rump, 2007; Lynch and Dembo, 2004; McLoughlin and Lee, 2010; Nicol, 2009; Nicol and Macfarlane-Dick, 2006; Sansone, Fraughton, Zachary, Butner and Heiner, 2011; Verhoeven, Heerwegh and Wit, 2012; Wirth and Leutner, 2008; Yukselturk and Bulut, 2009) and has extended its didactic approach with the objective of improving the quality of the learning and teaching process.

Lenne, Abel, Trigano and Adeline (2008) affirm that many higher education initiatives that aim to broaden the variety of activities for students tend to dismiss technological resources or to forget to help students to adapt to technological tools that are available to them and encourage self-regulated learning. 
The use of new methodological tools, such as new technologies, offers opportunities that can help students to manage and regulate their learning throughout the curriculum in a better and more effective way. Also, the use of social media such as WordPress, Twitter, Blogs, Wikis, Youtube, Facebook, and Linkedin, among others, opens the door to a broad range of technological tools that can foster management of one's own learning through their social aspect in educational settings.

In this regard, according to Dabbagh and Kitsantas (2012), both the schools and the students themselves are currently making an effort to generate new ways of teaching and learning that lead to the emergence of constructs such as e-learning 2.0 that increase personalization, collaboration, social networking and usergenerated content.

Moreover, they argue that the student's self-regulation of learning can be encouraged through the use of Personal Learning Environments (PLEs) defined as "a new construct in the e-learning literature that is premised on social media and steadily gaining ground in the e-learning field as an effective platform for student learning” (4) and empower them to organize, create and share content facilitating three fundamental aspects of learning management: the information management, identity management and relationship management.

Blogs are an educational tool which used appropriately can foster the development of the student's self-regulation skills and generate a continuous feedback between a student or students and a professor, among students, as well as students and the management of their proper knowledge through metacognitive strategies (Lee, 2011; Robertson, 2011).

Lee et al. (2010) believes that learning can be improved if different variables of self-regulation are worked on using new technologies and generating quality strategies through metacognitive feedback in view of the fact that management of one's own cognition is one of the most critical factors influencing learning. Along these lines, Hatzipanagos and Warburton (2009) affirm that the quality of feedback in open systems such as wikis and blogs is conditioned by the role of a good moderator or tutor that generates and fosters metacognitive feedback. Also, according to Nicol and Macfarlane-Dick (2006) a good approach that provides useful feedback as a part of an education system lies at the center of the inherent process that encourages self-regulation of learning. It rests on the following seven principles:

1. Helps clarify what good performance is (goals, criteria, expected standards);

2. Facilitates the development of self-assessment (reflection) in learning;

3. Delivers high quality information to students about their learning;

4. Encourages teacher and peer dialogue around learning;

5. Encourages positive motivational beliefs and selfesteem:

6. Provides opportunities to close the gap between current and desired performance;

7. Provides information to teachers that can be used to help shape teaching.

In this regard, the objective of this paper is to make evident that an effective use of an ICT resource for educational purposes can help to develop self-regulated learning competencies related to other skills of vital importance for lifelong learning. Consequently, we aim to foster future research focused on the measurement of the effectiveness of ICT use, both in absolute as well as relative terms. Since self-regulation of learning is a complex competency that requires the development of other skills, it would also be possible to conduct research on the relevance of each skill in regards to the development of self-regulated learning.

\section{Experimental Stage}

The goal of this didactic experience is to develop selfregulation learning skills through a systematic use of ICT's, in particular, a blog as a teaching and learning tool. It was implemented as a part of a Sociology of Education course whose content is mostly theoretical and requires an advanced level of reflection and internalization of concepts that were completely unfamiliar to the students.

In fact, though it is true that high school students study humanities disciplines, they do not always develop the intellectual habits (Polo, 2006) that allow them to accurately comprehend theoretical subjects.

On the other hand, since the development of said intellectual habits is required, both topics for rigorous reflection and directions to practice the four linguistic competencies related by definition to thinking such as listening, talking, reading and writing are offered. Among these competencies, our experience focuses on the two last ones, although active listening and a dialogue in class are also fostered.

The coursework requires that ample time be dedicated to the presentation of the fundamental concepts. Therefore, students' involvement might seem passive and it may be difficult for participants to become engaged in the learning process.

Specifically, the experiment is designed to: [a] encourage well-organized and consistent work habits by establishing sufficient periods of time for students that would give them enough autonomy to make decisions; [b] to promote reflection on topics covered in class; [c] to facilitate a dialogue among students that promotes the formation of a learning community.

Since the classes take place every week, students are required to submit a critical thinking blog post on the topics explained in class with the help of reference texts and articles subsequent to the class. The professor starts the discussion with the first post focusing on the topic that students have to reflect on and guiding them through questions. Students' comments will be part of the sets of other students' comments on a suggested text. The time limit to post a comment is one week. In this way, students have enough time to make decisions regarding their own learning and the development of learning self-regulation strategies which, as was mentioned above, involve cognitive, motivational, metacognitive and volition skills.

Upon the acquisition of the four types of competences, students' education is more complete than when all the resources are only centered on the two most common dimensions which are the cognitive and motivational.

In this respect, the importance of volition competences for self-regulation of learning is worth noting (Martín and 
Mauri, 2011), as they enable students to manage their learning. Time-management is undoubtedly a starting point for the development this kind of competence.

Students should use volitional strategies if they want to succeed in their learning (Boekaerts, 2009; Lee and Lee, 2012; Nocito, 2013). When they ought to finish a task on time, they often have to impose on themselves certain restrictions regarding their personal interests and wishes. It is not enough to be motivated. It is necessary that students manage their motivation until they achieve their goal and apply volitional strategies, in other words, take initiative, commit to the task and maintain the effort until completing it.

Specifically, the following skills could be observed in said project through students' assignments and activities:

1. Strengthened will, defined as perception of control over effective achievement of a weekly task. It also requires personal time management.

2. Increased motivation due to the fact that the goal of posting a comment of approximately 300 words was perceived by students as possible, in other words, manageable.

3. The completion of the task according to the previously established criteria consistently garners a positive evaluation and is then included as a percentage of the students' final grade. Therefore, the associated value of those tasks also reinforces students' motivation.

The data comes from the interviews conducted among students who participated in this project. They were focused on self-regulated learning strategies related to students' motivation and academic achievement.

The task itself requires reading, reflection and writing, in other words, it maximizes students' cognitive skills at a high level. Since the comments on the blog are visible to all the other students and they can make comments on the posts of their classmates, a community of learning is created, as well as a real collaborative teamwork that helps to clear up doubts about the course content and its implications in diverse areas, as is characteristic in Sociology of Education.

A professor makes comments that guide students' work, clarifying concepts when necessary and confirming correct answers. In this way, the process itself is educational and students' competency in diverse skills that the tasks require increases.

It is worth noting that teacher's interaction to students comments on the class blog make the course more dynamic and constitutes a positive reinforcement and feedback for students, as well as builds up their self-image thanks to the public recognition of their comments.

\section{Results and Discussion}

Blogs are considered to be a very useful tool due to their exceptional features that facilitate the achievement of the goals mentioned above, taking into account the needs of both students and professors.

These needs are related to the requirements of the European Higher Education Area which are aimed to foster self-regulation of learning that leads directly to developing cognitive, motivational and volitional skills.

As for the cognitive dimension, it has been proven as well, that texts intended to be published on blogs and read by others require a high degree of accuracy and reflection on the part of students.

Regarding other aspects outlined here, the project's assessment of the effectiveness of blog use in a classroom setting has not been carried out systematically but in an approximate way through students' surveys which indicated the following:

1. An increase in motivation was noted as applied to understanding and learning course material through individual study since all the material was previously explained in class and through reading, writing and selfreflection posted on the blog. In this case, motivation was increased by the students' perception of the ability to reach the stated goal successfully.

2. Students' reported a more positive self-image due to a significative amount of feedback which is given on the blog as well as in class during the teaching-learning process. Therefore, students continue receiving updates on their progress on required course tasks.

Students' perception due to the use of blogs, as well as individual study and comprehension of basic concepts of the course that were explained along the semester and not only evaluated at the end of the course had a positive impact on their final grade. Professors on their part observed greater student involvement in their learning process and an increase of self-regulation skills. Autonomous but supervised study seems to be the cause of the acquisition of those skills. Active participation in class has improved, as well.

\section{Conclusions}

Said project demonstrates that further research, both qualitative and quantitative in nature, on the impact of the use of blogs for the development of the competencies identified above, as well as a comparative study of results of students' learning with and without the use of blogs, is not only possible but would likely provide very useful data.

The hypothesis of this project could suggest a significative increase in improvement of student' learning self-regulated strategies.

It is possible that this future research could demonstrate a definitive positive correlation between the use of blogs and an improvement of students' self-regulated learning strategies.

One must also consider that the increased use of these strategies is an improvement of students' resources and personal competencies. Thus, it would be also worth studying the impact on the acquisition of the course material. Self-regulation learning strategies are students' skills that are not necessarily directly related to their coursework and areas of study, but instead to resources that students can use to manage their learning.

\section{References}

[1] Andrade, M. \& Bunker, E. (2009). A model for self-regulated distance language. Distance Education, 30 (1), 47-61.

[2] Azevedo, R. (2005). Computer environments as a metacognitive tool for enhancing learning. Educational Psychologist, 40, 193197. 
[3] Azevedo, R. (2010). Using hypermedia as a metacognitive tool for enhancing student learning? The role of self regulated learning. Educational Psychologist, 40 (4), 199-209.

[4] Azevedo, R. \& Cromley, J.G. (2004). Does training on selfregulated learning facilitate students' learning with hypermedia? Journal of Educational Psychology, 96, 523-535.

[5] Boekaerts, M. (2009). La evaluación de las competencias de autorregulación del estudiante. En C. Monereo (Coord.), Pisa como excusa: Repensar la educación para cambiar la enseñanza (pp.55 -59). Barcelona: Graó.

[6] Boekaerts, M., Maes, S. \& Karoly, P. (2005). Self-regulation across domains of applied psychology: is there an emerging consensus? Applied Psychology: An International Review, 54, 3351.

[7] Ciesielkiewicz, M. (2012, 9-10 July). Digital Humanities: The Electronic Language Portfolio as a Tool for Instruction and Evaluation. Paper presented at Global Science \& Technology Forum: L3 2012, Singapore.

[8] Commission of the European Communities. (2006) Recommendation of the European Parliament and of the Council on Key Competences of Lifelong Learning. Brussels. Retrieved from http://eur-lex.europa.eu/legalcontent/EN/TXT/PDF/?uri=CELEX:32006H0962\&from=EN, October 12, 2006.

[9] Commission of the European Communities. (2000). A Memorandum of Lifelong Learning. Brussels. Retrieved from http://tvu.acs.si/dokumenti/LLLmemorandum_Oct2000.pdf, March 20, 2006,

[10] Dabbagh, N. \& Kitsantas, A. (2012). Personal Learning Environments, social media, and self-regulated learning: A nautical formula for connectic formal and informal learning. Internet and Higher Education, 15 (3-8).

[11] European Commission. (2000). European Report on the Quality of School Education Sixteen quality indicators. Retrieved from http://aei.pitt.edu/42406/1/A6503.pdf, March 20, 2006.

[12] García, M. (2012). La autorregulación académica como variable explicativa de los procesos de aprendizaje universitario. Revista de curriculum y formación del profesorado, 16 (1). Retrieved from http://www.ugr.es/ recfpro/rev161ART12.pdf, July 12, 2012.

[13] Gargallo, B. \& Ferreas, A. (2000). Estrategias de aprendizaje: un programa de intervención para ESO y EPA. Madrid: MEC.

[14] Geddes, D. (2009). How am I doing? Exploring on-line gradebook monitoring as a self-regulated learning practice that impacts academic achievement. Academy of Management Learning \& Education, 8 (4), 994-510.

[15] González, A. (2001). Autorregulación del aprendizaje: una difícil tarea. Iberpsicología, 6 (1), 30-67.

[16] Grahame, M. \& Anderson, W.G. (2003). Handbook of distance education. Mahwah, NJ: Erlbaum.

[17] Hatzipanagos, S. \& Warburton, S. (2009). Feedback as a dialogue: exploring the links between formative assessment and social software in distance learning: Learning, Media and Technology, 34 (1), 45-59.

[18] Hernández, F., Rosario, P. \& Cuesta, J.D. (2010). Impacto de un programa de autorregulación del aprendizaje en estudiantes de Grado. Revista de Educación, 353, 571-587.

[19] Hofer, B., Yu, S. \& Pintrich, P. (1998). Teaching College students to be self-regulated learners. En D.H. Schunk y B.J. Zimmerman (Eds.), Self-regulated learning: from teaching to self-reflective practice (pp. 57-85). New York: Guilford.

[20] Kramarski, B. \& Michalsky, T. (2009). Investigating preservice teachers'professional growth in self-regulated learning environments. Journal of Educational Psychology, 101, 161-175

[21] Lee, L. (2011). Blogging; promoting learner autonomy and intercultural competence through study abroad. Language Learning \& Technology, 15 (3), 87-109.

[22] Lee, H. \& Lee, J. (2012). Who gets the best grades at top universities? An exploratory analysis of institution-wide interviews with the highest achievers at a top Korean University. Asia Pacific Education Review, 13, 665-676.

[23] Lee, H., Lin, K. Y. \& Grabowski, B.L. (2010). Improving selfregulation, learning strategy use, and achievement with metacognitive feedback. Education. Technology Research and Development, 58, 629-648.

[24] Lenne, D., Abel, M.H., Trigano, P. \& Adeline, L. (2008). Selfregulated learning in technology enhanced learning environment: an investigation with university students. Technology, Pedagogy and Education, 17 (3), 171-181.
[25] Leutner, D., Leopold, C. \& Elzen-Rump, V. (2007). Self-regulated learning with a text-highlighting strategy. Journal of Psychology, 215 (3), 174-182.

[26] Lloret, T. \& Mir, A. (2007). ¿Qué ha ocurrido en la implementación del EEES en algunas titulaciones?: Un primer balance en la UPF en términos de rendimiento académico, satisfacción y proceso de enseñanza aprendizaje. Red U. Revista de Docencia Universitaria, número 1. Retrieved from http://www.redu.um.es/Red_U/1/, May 30, 2010

[27] Lynch, R. \& Dembo, M. (2004). The relationship between selfregulation and online learning in blended learning context. International Review of Research in Open and Distance Learning, 5 (2), 1-16.

[28] Martín, E. \& Mauri, T. (2011). Orientación educativa. Atención a la diversidad y educación inclusiva. Barcelona: Graó.

[29] McLoughlin, C. \& Lee, M. (2010). Personalised and self regulated learning in the web 2.0 era: International exemplars of innovative pedagogy using social software. Australasian Journal of Educational Technology, 26 (1), 28-43.

[30] Monereo, C. (2001). La enseñanza estratégica. Enseñar para la autonomía. Aula de Innovación, 100, 6-10.

[31] Nicol, D. (2009). Assessment for learner self-regulation: enhancing achievement in the first year using learning technologies. Assessment \& Evaluation in Higher Education, 34 (3), 335-352.

[32] Nicol, D.J. \& Macfarlane-Dick, D. (2006). Formative assessment and self-regulated learning: a model and seven principles of good feedback practice. Studies in Higher Education, 31 (2), 199-218.

[33] Nocito, G. (2013). Self-regulated learning in undergraduate students. A case study. Madrid. University Complutense of Madrid. Retrieved from http://eprints.ucm.es/24036/1/T35049.pdf

[34] Núñez, J.C., González-Pienda, J.A. \& Rosario, P. (2006). Evaluación de los procesos de autorregulación mediante el autoinforme. Psicothema, 18 (3), 353-358.

[35] Polo, L. (2006). Curso de teoría del conocimiento. I. Pamplona: Eunsa.

[36] Pozo, J. I. \& Monereo, C. (Coords.). (2000). El aprendizaje estratégico. Madrid: Santillana.

[37] Randi, J. \& Corno, L. (2000).Teacher innovations in self-regulated learning. In M. Boekaerts, P.R. Pintrich \& M. Zeidner (Eds.), Handbook of self-regulation. San Diego, CA: Academic Press.

[38] Robertson, J. (2011). The educational affordances of blogs for self-directed learning. Computers \& Education, 57, 1628-1644.

[39] Román, J.M. (2004). Procedimiento de aprendizaje autorregulado para universitarios: la "estrategia de lectura significativa de textos”. Revista Electrónica de Investigación Psicoeducativa, 2 (1), 113-132.

[40] Sáinz, C., Montero, E., Bol, A. \& Carbonero, M. (2012). Un análisis de competencias de "aprender a aprender" en la universidad. Electronic Journal of Research in Educational Psychology, 10 (1), 253-270.

[41] Sansone, C., Fraughton, T., Zachary, J.l., Butner, J. \& Heiner, C. (2011). Self-regulation of motivation when learning online: the importance of who, why and how. Educational Technology Research Development, 59, 199-212.

[42] Sitzmann, T. \& Ely, K. (2011). A meta-analysis of self-regulated learning in work-related training and educational attainment: what we know and where we need to go. Psychological Bulletin, 137 (3), 421-422.

[43] Torrano, F. \& González, M.C. (2004). El aprendizaje autorregulado: presente y futuro de la investigación. Revista Electrónica de Investigación Psicoeducativa, 2 (1), 1-34.

[44] Torre, J.C. (2007). Una triple alianza para un aprendizaje universitario de calidad. Madrid: Universidad Pontificia de Comillas.

[45] Verhoeven, J., Heerwegh, D. \& Wit, K. (2012). First year university students 'self perception of ICT skills: Do learning styles matter? Education and Information Technologies, 17, 109133.

[46] Wirth, J. \& Leutner, L. (2008). Self regulated learning as a competence. Implication of theoretical Models for Assessment Methods. Journal of Psychology, 216 (2), 102-110.

[47] Yukselturk, E. \& Bulut, S. (2009). Gender differences in self regulated online learning environment. Educational Technology \& Society, 12 (3), 12-22.

[48] Zimmerman, B.J. (2008). Investigating self -regulation and motivation: Historical background, methodological developments, and future prospects. American Educational Research Journal, 45, 166-183. 